\title{
Assessment of Impact of Recreational Resorts on Socio-Economic Growth of Calabar, Cross River State - Nigeria
}

\author{
T.E. Amalu ${ }^{1 *}$, P.A. Ojugbo ${ }^{2}$, O.O. Otop ${ }^{3}$ \\ 1,2,3 Department of Geography and Environmental Science, University of Calabar, Cross River \\ State, Nigeria \\ *titiagento@gmail.com
}

Keywords: Tourism, Development, Recreational Centres, Resorts, Patronage, Nigeria.

\begin{abstract}
This study examined the influence of the tourism industry on socio-economic growth of Calabar, Cross River State with special interest on the role of the resorts operating within the study area. Primary and secondary sources of data were employed for the study. The primary source involved the use of questionnaires, interview with participatory research appraisal methods while the secondary sources involved the use of journals, textbooks and records from the management of the various resorts within the area. The study observed that the highest medium of awareness of the existence of the resorts was through family and friends leading to $36 \%$ of the entire visitors to the resorts. It was also observed that $89 \%$ of the employed workers in the resorts were residents of the study area. The study analysis revealed that the number of employed workers in the resorts varied significantly across the various resorts with $\mathrm{F}=5.243 ; \mathrm{P}<0.05$ and also a significant variation across the class of employment with $\mathrm{F}=8.383 ; \mathrm{P}<0.05$. The study also observed that the resorts provided opportunities for employment, generation of more income and infrastructural enhancement within the area. Based on these findings, it was therefore recommended that government of Cross River State should direct interest in investing in the tourism industry through collaboration with private investors and providing an enabling business environment by the reduction of tax, provision of loan facilities and provision of infrastructures in the study area.
\end{abstract}

\section{Introduction}

The quest for leisure in recent times has called for a growing demand for recreational activities across major cities of the world today [1]. Tourism have been touted as a panacea to improving the socio-economic status of destination areas with growing government and private sector interest in major developed countries and cities.

The development and establishment of the Nigeria Tourism Development Corporation (NTDC) with the aim to boost the growth of tourism has encouraged the development and rehabilitation of most existing recreational resorts [2]. Meanwhile, resort centres such as the Obudu Mountain resort, Marina resort, Tanapa resort, Eko Tourist Resort, Yakari Game Reserve, Ikogosi Warm Spring, Ezeagu recreational centre amongst other tourism attractions have needs for many tourists and fun-seekers visiting and patronizing the resorts [3-6]. These laudable recreational resorts provide numerous recreational facilities for both indoor and outdoor games to tourists and visitors during their leisure time $[4,7]$.

In Cross River State, the bid to improve the economy has necessitated the rapid development and rehabilitation of available tourism potentials. These potentials include Obudu Ranch Resort, Kwa Fall; Marina resort, Tinapa Business Resort and others whose aim is to provide leisure and recreation opportunities to various categories of people and visitors in the State [8-10]. However, irrespective of the numerous tourism activities and availability of recreational resorts in Calabar metropolis, there has been a loud-cry of lack of patronage of most resorts which have prompted the closure or inactivity of some resorts in the area. Unfortunately, little or no study has been carried out to examine the pattern of patronage of recreational resorts in the area. It is in this regards that this study seeks to investigate the pattern of patronage and benefits of recreational resorts in Calabar, Cross River State. 


\section{Literature Review}

Recreation and leisure is a subset of tourism and hospitality [10]. The word "recreation" can be defined in several ways depending on individual's perspective [11]. Recreation could be described as involving the act of watching television, attending an opera, base jumping, mowing the lawn, visiting the zoo, listening to music, visiting a drinking spot for some chilled drink, visiting a restaurant to eat a palatable dish [6]. The paramount point to note is that recreation is an activity which does not occur in isolation but must take place in a place and possibly with the aid of some facilities or amenities [10].

In broad sense $[12,13]$ have highlighted the fact that leisure and recreation reflects the fundamental values and character of a region or destination.

In recent times, scholars $[9,14]$ have retorted that recreation helps to shape the character and wellbeing of people, families, communities and society at large. Recreation have been observed as one of the way of overcoming barriers to community development $[15,16]$ through the number of tourists who visit available recreational facilities such as resorts, attractions, drinking spots, restaurants and hotels in most host communities.

Recreation may be associated with environmental concerns because of the impact of direct sensory experience or distinctive demographic characteristics of participants in particular forms of recreational activities [17].

$[14,18]$ reported that parks and recreational facilities provide opportunities for physical activity and can people of all ages live a more active lifestyle. People who live near and recreational centres are more likely to be more active. However, some low income earners and rural communities tend to have less access to quality parks and resort facilities. [6] in a study of the impact of recreation on community development emphasized that making recreational resorts accessible and affordable in all communities is a crucial strategy for increasing physical activities and preventing some illnesses such as obesity and fatigue. [19] suggests that everyone needs recreation and as such recreation is a source of casual fun or pleasure and maybe passive or active. Whatever the form, people can always create their own means of recreation.

In terms of customer satisfaction, [18] suggest that quality service and provision of standard facilities such as spa, gym, restaurant, lawn and accommodation helps to enhance the choice of a recreational centre in destination area. They also emphasized that distance was a major determinant factor in patronage of recreational facilities as also distance of various support facilities from the resort or recreation centres plays a vital role in improving customer satisfaction. [20] stressed that proximity determines and encourages more appraisal of recreational centre within a destination regions. It is in this regards that this study seek to examine the available recreational facilities in Calabar metropolis and more so, examine the proximity of the recreational centres and facilities from each other. The growing interest in tourism development in Cross River State especially in Calabar has aided the emergence and rapid growth of most recreational resorts in Calabar. Some of the emerging recreation centres include; Aqua Vista, Marina Resort, Orange Resort and the rehabilitation of both Botanical Garden and the Old Residency 'Museum' which provide different opportunities and services to many fun-seekers visiting Cross River State in general and Calabar in particular. Today, these great resorts in Calabar have also caused the emergence of other tourism support services such as laundry services, mobile phone operators, restaurants and other auxiliary tourism support services which provide essential services to numerous visitors in the state [14, 21]. Nevertheless, the presence of the unique recreational resorts has really helped to position Cross River State as a tourism destination in the world [6].

There is growing interest in the demand for recreational activities especially, in tourism and resort facilities. Many countries rely on the dynamic features of the tourism and hospitality industry as a primary source for socio-economic development such as income or revenue generation, job or investment opportunities, private investor's involvement and infrastructural growth to promote human and community development. Resort development is encouraged particularly among the developing countries around the world, where other forms of economic activities such as manufacturing or exportation of natural resources are not commercially viable [22, 23]. 
Tourism which involves the movement of people from one place to another has become a major catalyst that has seriously propelled the rising demand for recreational activities in most countries in Africa [13, 17, 20]. Recreation could be described as the activity that provides the means by which leisure quest and experiences are satisfied. In most cases, these recreational activities take place in resorts established to provide tourism products and services [20, 24, 25].

A resort is a place used for relaxation or recreation, attracting visitors for vacations and for tourism. [26-29] considered resorts as one of the vital tourism products in recent decades. The increase in recreational resorts in most cities in the world today have not only aided economic growth but have at the same time encouraged the emergence of other tourism support services such as hotel industry, communication and even transport industry which provides essential services to tourist and visitors [30-32].

\section{Study Area}

Calabar metropolis is in Cross River State. It is located at the southern part of Nigeria between $4^{\circ} 58^{\prime} 58.3428^{\prime \prime} \mathrm{N}$ and $8^{\circ} 20^{\prime} 4.2108^{\prime \prime} \mathrm{E}$ (Fig. 1). The city of Calabar metropolis is one of the largest coastal cities of Nigeria known also as Canaan City, and it is located in the very mouth of the Cross River. The State is endowed with numerous tourism and cultural sites and events respectively. Calabar metropolis is a endowed with lots of tourism sites and activities such as the marina resort, Calabar carnival, Tinapa business resort, national museum, slave trade museum, Aqua-vista resort, Orange resort. 


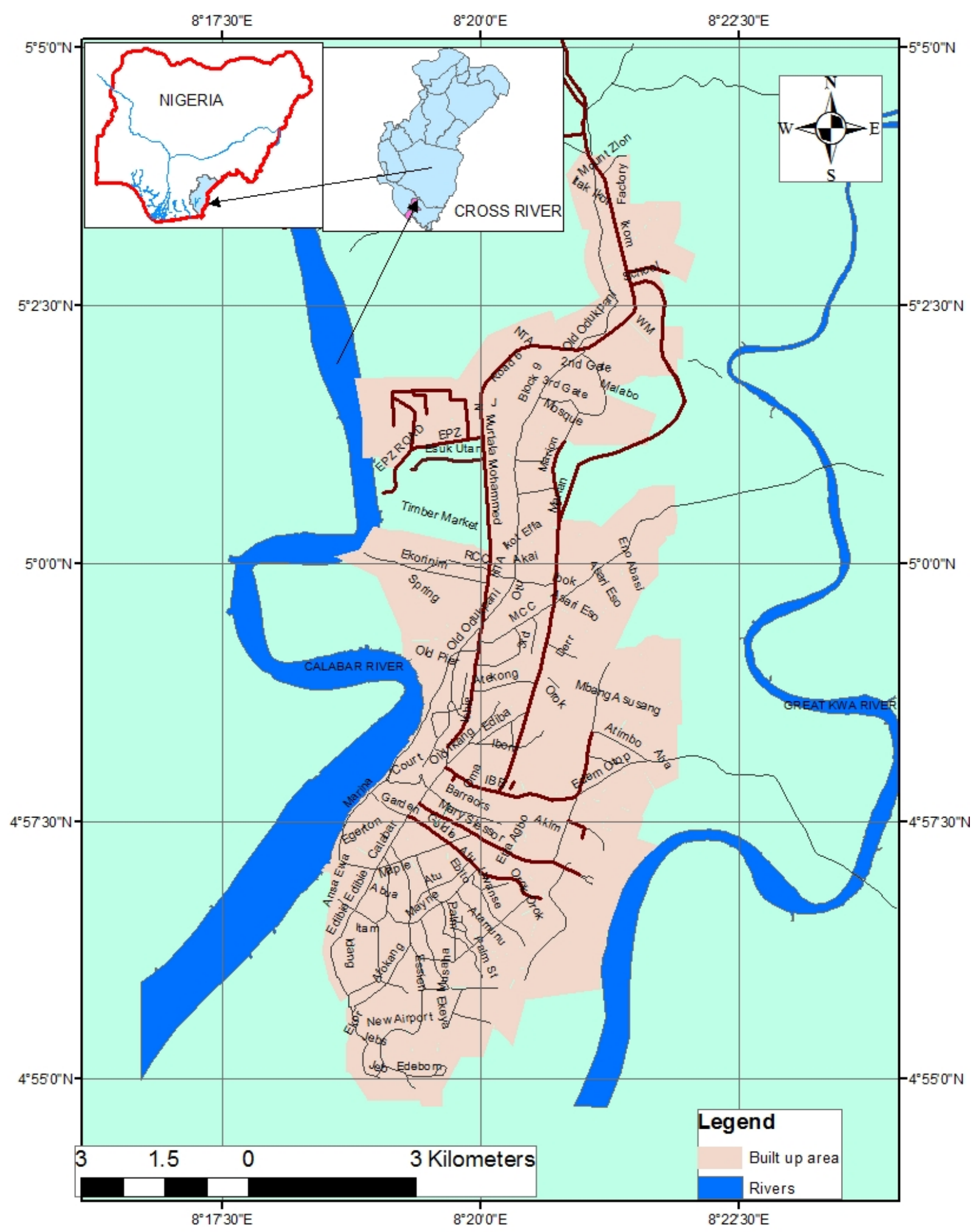

Figure 1. Map showing the study area

\section{Methodology}

Cross sectional and causal research design were adopted for the study. The cross sectional design was adopted because the study seeks to examine the socio-economic influence of recreational resorts within Calabar metropolis [33, 34]. Researchers causal design was adopted because the study will involve an in depth investigation of the subject matter to enable the researcher fully understand the economic implications of the recreational resorts to the people and economy of the study area. Primary and secondary sources of data collection were used to obtain 
data for the study. The primary source involved the use of questionnaires, participatory research appraisal methods while the secondary source involved the use of information from journals, textbooks, records from the management of the various resorts within the area. Two sets of questionnaire were administered to help elicit information for the study. The first was administered to residents staying around the various resorts in the area to examine the visitors' awareness of the resort, the type of recreational activities they participated in and the extent to which the resort was beneficial or detrimental to them. The second was administered to management of the resorts to help the researcher elicit information on the number of visits, patronage, number of staffs, remuneration of the staffs and how much income workers in the resort generated.

Information for the study was derived from a survey of household heads within Calabar metropolis in January, 2018 to help the researcher(s) investigate the socio-economic implications of recreational resorts in the area. Interviews were also conducted with focus persons such as; managers of resorts, hotels, elders, women leaders and leaders of youth groups. The study area is made up of a total household heads of 9,598. Meanwhile, 10 percent of the total households were selected for this study as they make up the active age. The questionnaire survey involved 960 household heads as 960 questionnaires were administered and successfully completed and returned.

Data collected was presented with the aid of tables, graphs, charts, mean, standard deviation and simple percentages and the data analyzed using inferential statistical techniques with the aid of SPSS version 16 software.

\section{Results and Discussion}

\section{Visitor's medium of awareness of the recreational resort}

Information on Table 1 revealed that out of 1148 interviewed customers that visited the recreational resorts in the area, 422 people representing 36 percent of the customers got knowledge of the resort through friends. 255 visitors representing 21 percent of the entire customers got knowledge of the resort through advert on sign posts while 139 persons and 150 persons representing 12 percent and 13 percent of the customers had knowledge of the resort through the electronic and print media respectively. This clearly shows that majority of people who visited the recreational resorts in the area had the knowledge of the resort through friends and family members who took them there in the first occasion or told them about their own experience in the resort. Meanwhile, the least source was the electronic media and this could be traced to the low educational level and poor reading culture of the people. The information is further illustrated on Fig. 2. It was also revealed through the interview sessions that friend's recommendation is the easiest means or medium of awareness of the resorts.

Table 1. Medium of awareness of the resorts

\begin{tabular}{|l|c|c|c|c|c|c|}
\hline \multicolumn{1}{|c|}{ Medium } & $\begin{array}{c}\text { Friends } \\
\text { F (\%) }\end{array}$ & $\begin{array}{c}\text { Sign post } \\
\text { F (\%) }\end{array}$ & $\begin{array}{c}\text { Print media } \\
\text { F (\%) }\end{array}$ & $\begin{array}{c}\text { Electronic } \\
\text { media } \\
\text { F (\%) }\end{array}$ & $\begin{array}{c}\text { Social } \\
\text { media } \\
\text { F (\%) }\end{array}$ & Total (F) \\
\hline Marina resort & $170(38)$ & $99(22)$ & $54(12)$ & $45(10)$ & $80(18)$ & 448 \\
\hline Orange resort & $101(39)$ & $57(22)$ & $26(10)$ & $29(11)$ & $47(18)$ & 260 \\
\hline Aqua Vista & $71(42)$ & $25(15)$ & $20(12)$ & $17(10)$ & $35(21)$ & 168 \\
\hline Harbour resort & $54(50)$ & $35(32)$ & $9(8)$ & $15(14)$ & $17(16)$ & 108 \\
\hline Nesville resort & $26(16)$ & $39(24)$ & $41(25)$ & $33(20)$ & $25(15)$ & 164 \\
\hline Total & $422(36)$ & $255(21)$ & $150(13)$ & $139(12)$ & $204(18)$ & 1148 \\
\hline
\end{tabular}

Source: Researcher's field survey, 2018 


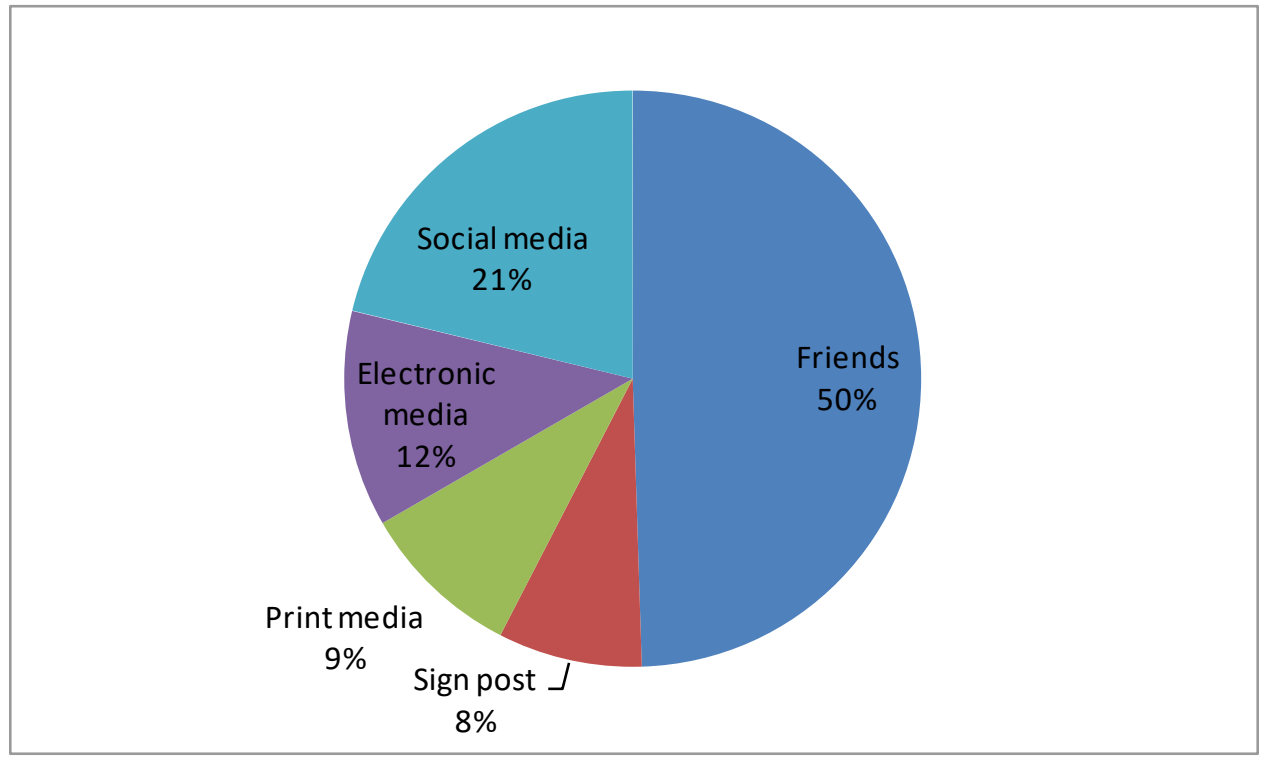

Source: Researcher's field survey, 2018

Figure 2. Medium of awareness of the recreational resort

\section{Employment structure in the major recreational resorts in the area}

The study examined the employment structure within the recreational resorts. Table 2 revealed that a total of 179 people were employed in the recreational resorts under investigation with the number of cleaners having the highest number of employed staffs with 44 people, closely followed by Receptionist and security staffs with 30 people respectively while the chef and laundry attendants recorded the least number of employed staffs with 7 people each. Table 3 further shows the total monthly average income the employed workers earn as monthly remunerations. It was realized that a total of $\mathrm{N} 2,408,500$ (two million, four hundred and eight thousand and five hundred naira) was earned by all the staffs working in the various major recreational resorts as monthly remuneration. Further investigation as shown in Fig. 3 shows that $89 \%$ of the workers were residents of the study area while $11 \%$ of the workers were non-residents, hence lived outside the study area territory.

Table 2. Employment structure of the recreational resorts in the area

\begin{tabular}{|c|l|c|c|c|c|c|c|}
\hline S/N & $\begin{array}{l}\text { Employment } \\
\text { structure }\end{array}$ & $\begin{array}{c}\text { Marina } \\
\text { resort } \\
\mathrm{F}\end{array}$ & $\begin{array}{c}\text { Orange } \\
\text { resort } \\
\mathrm{F}\end{array}$ & $\begin{array}{c}\text { Aqua-vista } \\
\text { resort } \\
\mathrm{F}\end{array}$ & $\begin{array}{c}\text { Harbour } \\
\text { resort } \\
\mathrm{F}\end{array}$ & $\begin{array}{c}\text { Nesville } \\
\text { resort } \\
\mathrm{F}\end{array}$ & $\begin{array}{c}\text { Total } \\
\mathrm{F}\end{array}$ \\
\hline 1 & Managers & 8 & 3 & 2 & 1 & 2 & 16 \\
\hline 2 & Cook/chef & 1 & 2 & 1 & 1 & 2 & 7 \\
\hline 3 & Receptionist & 12 & 6 & 2 & 6 & 4 & 30 \\
\hline 4 & Laundry attendant & - & 2 & 1 & 2 & 2 & 7 \\
\hline 5 & Security & 14 & 5 & 2 & 4 & 5 & 30 \\
\hline 6 & Bar attendant & 8 & 4 & 3 & 4 & 5 & 24 \\
\hline 7 & Cleaners & 10 & 8 & 6 & 10 & 10 & 44 \\
\hline 8 & Drivers & 2 & 3 & 1 & 2 & 3 & 11 \\
\hline 9 & Accountants & 2 & 2 & 1 & 2 & 3 & 10 \\
\hline 10 & Total & 57 & 35 & 19 & 32 & 36 & 179 \\
\hline
\end{tabular}

Source: Researcher's field survey, 2018 
Table 3. Total average monthly remuneration by the employed staffs of the resorts

\begin{tabular}{|c|l|c|c|c|c|c|c|}
\hline $\mathrm{S} / \mathrm{N}$ & $\begin{array}{l}\text { Employment } \\
\text { structure }\end{array}$ & $\begin{array}{c}\text { Marina } \\
\text { resort (N) }\end{array}$ & $\begin{array}{c}\text { Orange } \\
\text { resort (N) }\end{array}$ & $\begin{array}{c}\text { Aqua-vista } \\
\text { resort (N) }\end{array}$ & $\begin{array}{c}\text { Harbour } \\
\text { resort } \\
(\mathrm{N})\end{array}$ & $\begin{array}{c}\text { Nesville } \\
\text { resort (N) }\end{array}$ & $\begin{array}{c}\text { Total } \\
(\mathrm{N})\end{array}$ \\
\hline 1 & Managers & 320,000 & 75,000 & 30,000 & 30,000 & 40,000 & 495,000 \\
\hline 2 & Cook/chef & 27,000 & 70,000 & 18,000 & 30,000 & 60,000 & 205,000 \\
\hline 3 & Receptionist & 144,000 & 72,000 & 20,000 & 90,000 & 48,000 & 374,000 \\
\hline 4 & $\begin{array}{l}\text { Laundry } \\
\text { attendant }\end{array}$ & - & 16,000 & 6,000 & 20,000 & 20,000 & 62,000 \\
\hline 5 & Security & 112,000 & 40,000 & 16,000 & 40,000 & 60,000 & 268,000 \\
\hline 6 & Bar attendant & 80,000 & 40,000 & 24,000 & 48,000 & 60,000 & 252,000 \\
\hline 7 & Cleaners & 102,500 & 56,000 & 36,000 & 96,000 & 104,000 & 394,000 \\
\hline 8 & Drivers & 24,000 & 36,000 & 10,000 & 30,000 & 48,000 & 148,000 \\
\hline 9 & Accountants & 60,000 & 28,000 & 12,000 & 50,000 & 60,000 & 210,000 \\
\hline 10 & Total & 869,500 & 433,000 & 172,000 & 434,000 & 500,000 & $2,408,500$ \\
\hline
\end{tabular}

Source: Researcher's field survey, 2018

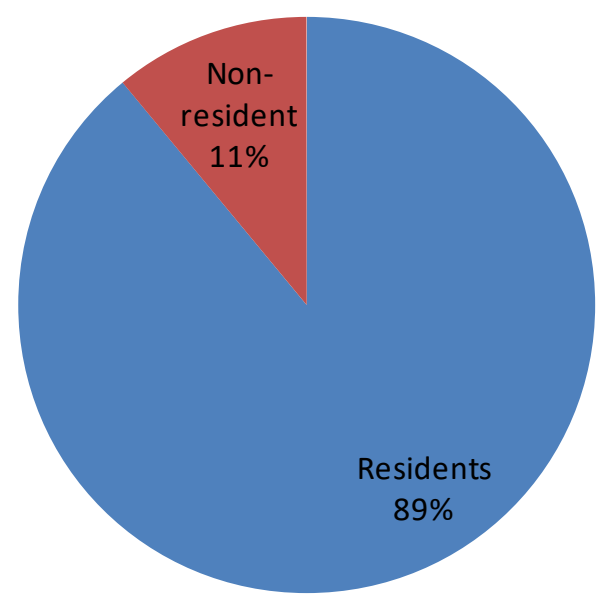

Figure 3. Origin of the workers of the recreational resorts in the study area

$\mathrm{H}_{0}$ : Employment structure does not significantly vary from one another in the various recreational resorts in the study area.

This hypothesis was tested using the analysis of variance (ANOVA) to help evaluate the difference in mean between the variables under investigation.

To test this hypothesis two way Analysis of variance was used with data on Table 2. The result as presented in Table 4 shows the sample size of the two variables (resort and class of employment). The data in Table 5 and 6 show the mean of number of employment across the resorts and the different categories of employment. It shows that marina resort has the highest mean $(\bar{X}=6.333)$ among the resorts, while Aqua vista has the least $(\bar{X}=2.111)$. Across the various class of employment, cleaners are the highest in number $(\bar{X}=8.800)$ followed by security and receptionists $(\bar{X}=6.000)$, while the least is cook/chef and laundry attendants $(\bar{X}=1000)$ respectively. Moreover, the test of significance in the test of between subject effects (Table 6) indicates a significant F-ratio for number of employment across the different resort $(\mathrm{F}=5.243$; $\mathrm{P}<0.05)$. This indicates that the number of employment varies significantly across the various resorts. Likewise, the variation is observed across the various class of employment with a significant F-ratio $(\mathrm{F}=8.383 ; \mathrm{P}<0.05)$. The variation is further shown in the mean plot in Fig. 4 and 5. However, the combine effect was not significant. 
Thus, with the result of the analysis showing significant F-ratio across the resorts $(\mathrm{F}=5.243$; $\mathrm{P}<0.05)$. The null hypothesis is rejected while the alternate is upheld meaning that employment structure significantly varies from one another in the various recreational resorts in the study area.

Table 4. Descriptive analysis of level of employment in the recreational resorts

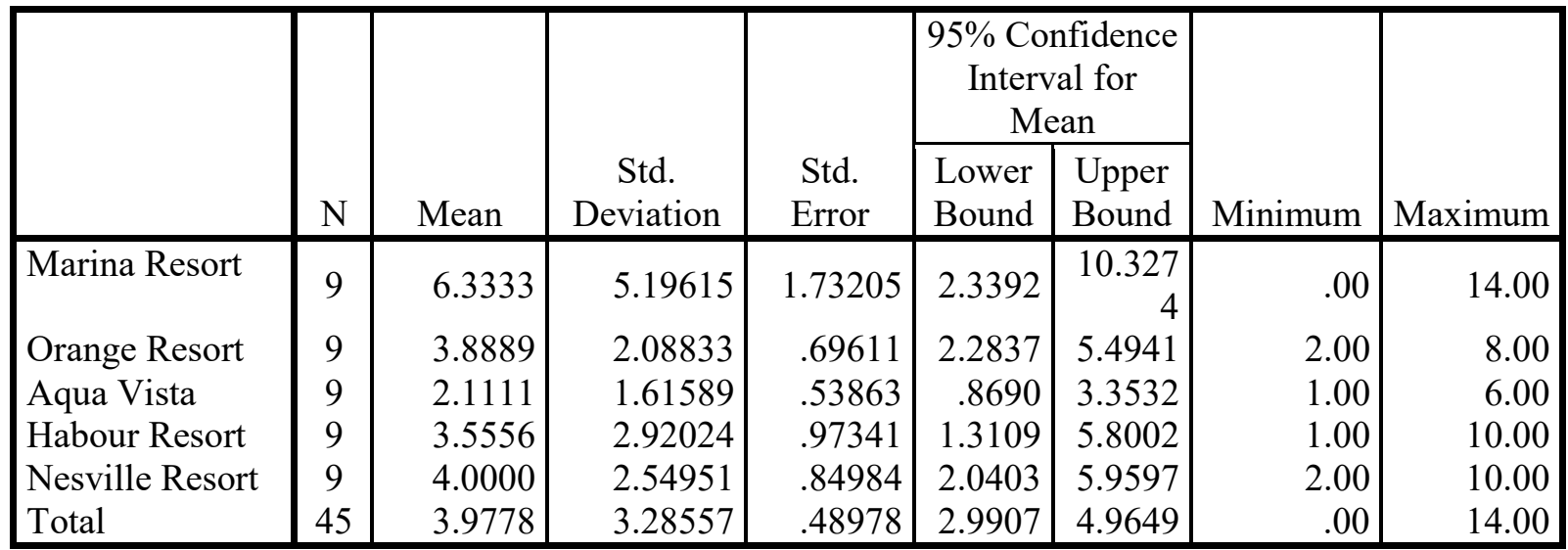

Table 5. Descriptive analysis of the types of staffs in the recreational resorts

\begin{tabular}{|c|c|c|c|c|c|c|c|c|}
\hline & \multirow[b]{2}{*}{$\mathrm{N}$} & \multirow[b]{2}{*}{ Mean } & \multirow[b]{2}{*}{$\begin{array}{c}\text { Std. } \\
\text { Deviation }\end{array}$} & \multirow[b]{2}{*}{$\begin{array}{l}\text { Std. } \\
\text { Error }\end{array}$} & \multicolumn{2}{|c|}{$\begin{array}{l}95 \% \text { Confidence } \\
\text { Interval for Mean }\end{array}$} & \multirow[b]{2}{*}{ Minimum } & \multirow[b]{2}{*}{ Maximum } \\
\hline & & & & & $\begin{array}{l}\text { Lower } \\
\text { Bound }\end{array}$ & $\begin{array}{l}\text { Upper } \\
\text { Bound }\end{array}$ & & \\
\hline Manager & 5 & 3.2000 & 2.77489 & 1.24097 & -.2455 & 6.6455 & 1.00 & 8.00 \\
\hline Cook/Chef & 5 & 1.4000 & .54772 & .24495 & .7199 & 2.0801 & 1.00 & 2.00 \\
\hline Receptionist & 5 & 6.0000 & 3.74166 & 1.67332 & 1.3541 & 10.6459 & 2.00 & 12.00 \\
\hline $\begin{array}{l}\text { Laundry } \\
\text { Attendant }\end{array}$ & 5 & 1.4000 & .89443 & .40000 & .2894 & 2.5106 & .00 & 2.00 \\
\hline Security & 5 & 6.0000 & 4.63681 & 2.07364 & .2426 & 11.7574 & 2.00 & 14.00 \\
\hline Bar attendants & 5 & 4.8000 & 1.92354 & .86023 & 2.4116 & 7.1884 & 3.00 & 8.00 \\
\hline Cleaners & 5 & 8.8000 & 1.78885 & .80000 & 6.5788 & 11.0212 & 6.00 & 10.00 \\
\hline Drivers & 5 & 2.2000 & .83666 & .37417 & 1.1611 & 3.2389 & 1.00 & 3.00 \\
\hline Accountant & 5 & 2.0000 & .70711 & .31623 & 1.1220 & 2.8780 & 1.00 & 3.00 \\
\hline Total & 45 & 3.9778 & 3.28557 & .48978 & 2.9907 & 4.9649 & .00 & 14.00 \\
\hline
\end{tabular}

Table 6. Tests of Between-Subjects Effects of the level of employment in the resorts

\begin{tabular}{|c|c|c|c|c|c|c|}
\hline Source & & $\begin{array}{l}\text { Type III Sum } \\
\text { of Squares }\end{array}$ & $\mathrm{df}$ & Mean Square & $\mathrm{F}$ & Sig. \\
\hline \multirow[t]{2}{*}{ Intercept } & Hypothesis & 712.022 & 1 & 712.022 & 21.464 & .002 \\
\hline & Error & 265.378 & 8 & $33.172^{\mathrm{a}}$ & & \\
\hline \multirow[t]{2}{*}{ Resort } & Hypothesis & 82.978 & 4 & 20.744 & 5.243 & .002 \\
\hline & Error & 126.622 & 32 & $3.957^{b}$ & & \\
\hline \multirow[t]{2}{*}{ Class_of_Employment } & Hypothesis & 265.378 & 8 & 33.172 & 8.383 & .000 \\
\hline & Error & 126.622 & 32 & $3.957^{\mathrm{b}}$ & & \\
\hline Resort * & Hypothesis & 126.622 & 32 & 3.957 & & \\
\hline Class_of_Employment & Error & .000 & 0 &. & & \\
\hline
\end{tabular}
a. MS(Class of Employment)
b. MS(Resort* Class_of_Employment)
c. MS(Error) 


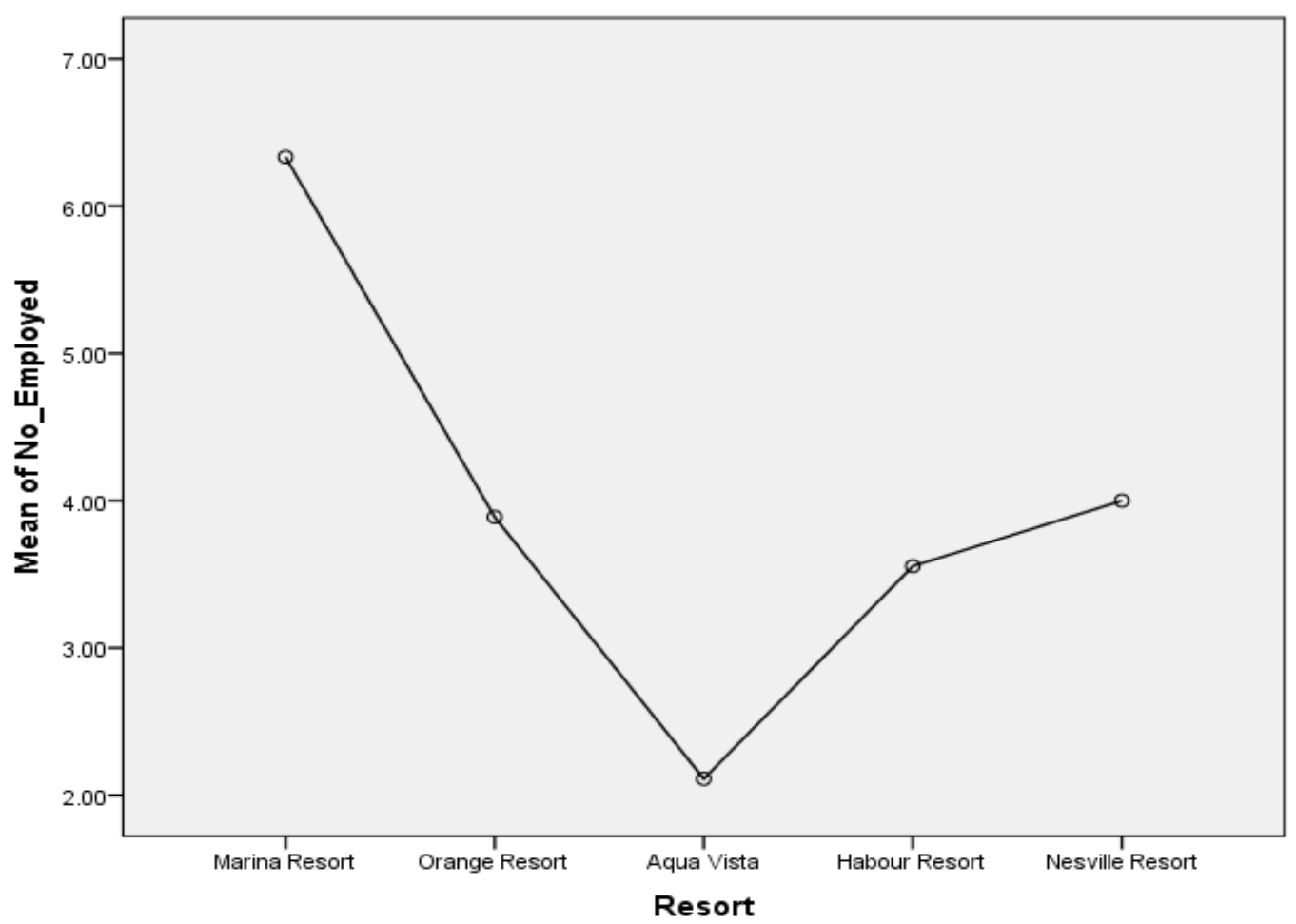

Figure 4. Mean plot for the variation of employment across the various resort.

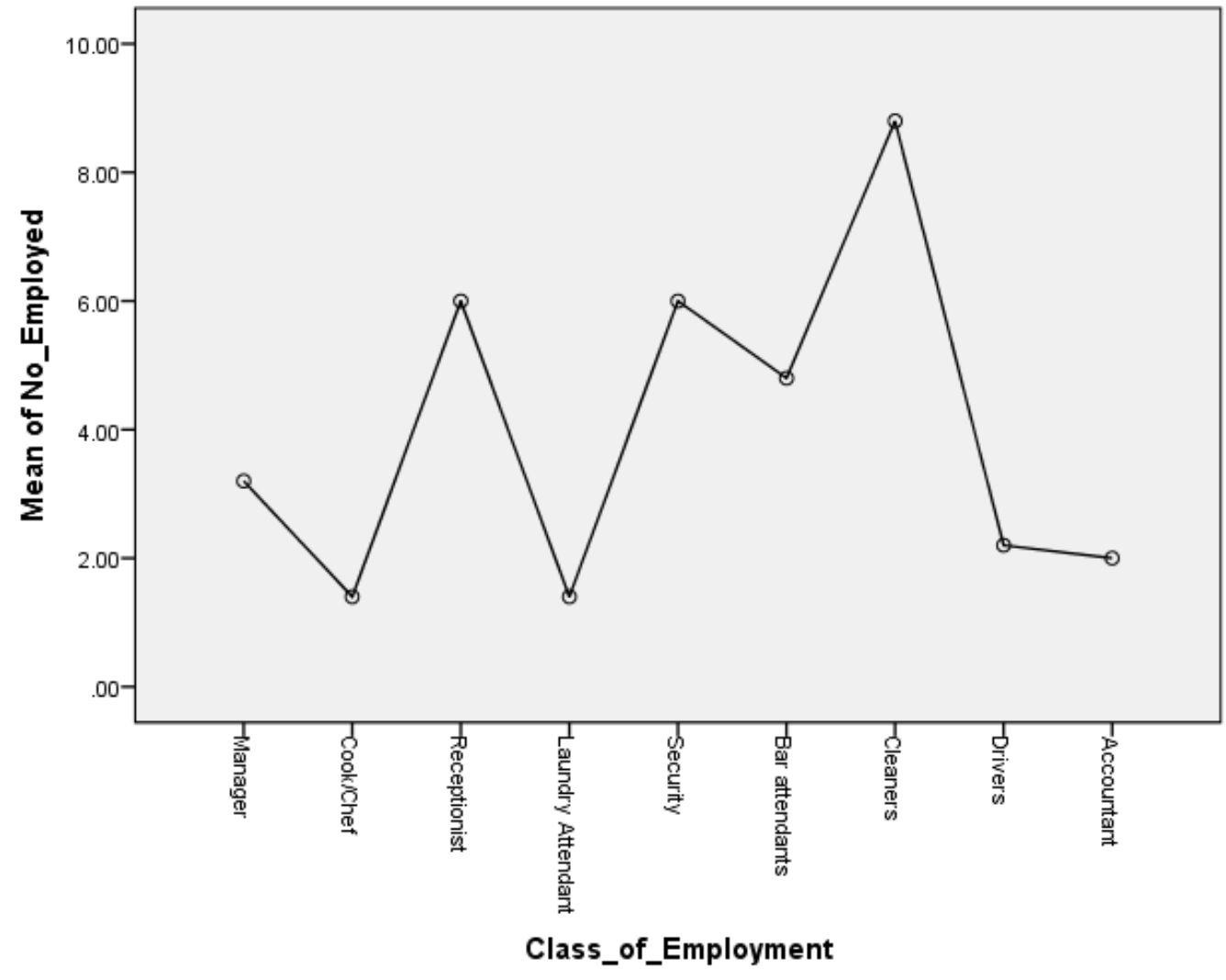

Figure 5. Mean plot of the variation across the class of employment

\section{Benefits and challenges of the recreational resorts to the people}

In terms of the benefits accruing from the existence of the recreational resorts in the area, it was observed in Table 7, that the resorts contributed to the welfare of the people by providing business opportunities to the people as it rated first on the response scale, closely followed by the provision of jobs and then increase in income. Meanwhile, the least benefit of the resort was said to be that it contributes to the improvement of the health of the people. Further investigation through the 
interview sessions indicates that the people lacked the knowledge of how important or relevant recreational activities are to health advancement.

Table 7. Ranking of benefits of the recreational resorts in the area

\begin{tabular}{|l|c|c|c|c|c|c|c|c|c|c|c|c|}
\hline Benefits & $\begin{array}{c}\text { Marina } \\
\text { Resort }\end{array}$ & $\%$ & $\begin{array}{c}\text { Orange } \\
\text { resort }\end{array}$ & $\%$ & $\begin{array}{c}\text { Aqua- } \\
\text { vista }\end{array}$ & $\%$ & $\begin{array}{c}\text { Harbour } \\
\text { resort }\end{array}$ & $\%$ & $\begin{array}{c}\text { Nesville } \\
\text { resort }\end{array}$ & $\%$ & Total & Rank \\
\hline $\begin{array}{l}\text { Provision of } \\
\text { employment }\end{array}$ & 545 & 18 & 354 & 21 & 1910 & 20 & 404 & 20 & 1289 & 18 & 4502 & 2 \\
\hline $\begin{array}{l}\text { Increase in } \\
\text { income }\end{array}$ & 576 & 19 & 368 & 21 & 1877 & 19 & 421 & 21 & 1178 & 16 & 4420 & 3 \\
\hline $\begin{array}{l}\text { Infrastructural } \\
\text { development }\end{array}$ & 452 & 15 & 257 & 15 & 990 & 10 & 210 & 10 & 999 & 14 & 2908 & 5 \\
\hline $\begin{array}{l}\text { Improved } \\
\text { health }\end{array}$ & 242 & 8 & 98 & 6 & 569 & 6 & 198 & 10 & 670 & 9 & 1777 & 7 \\
\hline Exposure & 275 & 9 & 224 & 13 & 1002 & 10 & 265 & 13 & 1190 & 16 & 2956 & 4 \\
\hline $\begin{array}{l}\text { Business } \\
\text { opportunity }\end{array}$ & 524 & 17 & 321 & 19 & 1998 & 21 & 411 & 20 & 1290 & 18 & 4544 & 1 \\
\hline $\begin{array}{l}\text { Clean } \\
\text { environment }\end{array}$ & 456 & 15 & 102 & 6 & 1324 & 14 & 100 & 5 & 678 & 9 & 2660 & 6 \\
\hline Total & 3070 & 13 & 1724 & 7 & 9670 & 41 & 2009 & 8 & 7294 & 31 & 23767 & \\
\hline
\end{tabular}

Source: Researcher's field survey, 2018

The study also examined the challenges of the recreational resorts as shown in Table 8 . The study used 5 point likert scale questionnaire to elicit information to actualize the objective. The response which was ranked from 1 to 5 with 1 being the least score (strongly disagree) and 5 being the highest score (strongly agree) was summed up and the percentage representation of each subject determined. Table 8 revealed that lack of publicity was the greatest challenge of the resort in the area with 4761 total responses and ranked as the first in the scale, closely followed by the issue of lack of maintenance and then increase in late night activities. However, the least challenge of the resort was noted to be the lack of trained staffs in the recreational resort.

Table 8. Ranking of the challenges of the recreational resorts in the area

\begin{tabular}{|l|c|c|c|c|c|c|c|c|c|c|c|c|}
\hline Challenges & $\begin{array}{c}\text { Marina } \\
\text { resort }\end{array}$ & $\%$ & $\begin{array}{c}\text { Orange } \\
\text { resort }\end{array}$ & $\%$ & $\begin{array}{c}\text { Aqua- } \\
\text { vista }\end{array}$ & $\%$ & $\begin{array}{c}\text { Harbour } \\
\text { resort }\end{array}$ & $\begin{array}{c}\text { Nesville } \\
\text { resort }\end{array}$ & Total & Rank \\
\hline Poor admin. & 344 & 7 & 354 & 10 & 1789 & 9 & 389 & 11 & 1201 & 10 & 4077 & 4 \\
\hline $\begin{array}{l}\text { Lack of } \\
\text { maintenance }\end{array}$ & 435 & 8 & 301 & 9 & 1501 & 8 & 257 & 7 & 1890 & 16 & 4384 & 2 \\
\hline $\begin{array}{l}\text { Lack of } \\
\text { publicity }\end{array}$ & 479 & 9 & 332 & 9 & 1980 & 10 & 402 & 12 & 1568 & 13 & 4761 & 1 \\
\hline $\begin{array}{l}\text { Insufficient } \\
\text { space }\end{array}$ & 324 & 6 & 298 & 9 & 980 & 5 & 311 & 9 & 1265 & 10 & 3178 & 10 \\
\hline $\begin{array}{l}\text { Lack of } \\
\text { facilities }\end{array}$ & 289 & 6 & 312 & 9 & 1879 & 10 & 288 & 8 & 890 & 7 & 3658 & 5 \\
\hline $\begin{array}{l}\text { High cost of } \\
\text { commodities }\end{array}$ & 462 & 9 & 198 & 6 & 1999 & 10 & 243 & 7 & 679 & 6 & 3581 & 7 \\
\hline $\begin{array}{l}\text { Pollute the } \\
\text { environment }\end{array}$ & 428 & 8 & 348 & 10 & 1781 & 9 & 190 & 5 & 557 & 5 & 3304 & 9 \\
\hline $\begin{array}{l}\text { Lack of trained } \\
\text { staff }\end{array}$ & 408 & 8 & 333 & 10 & 1232 & 6 & 187 & 5 & 460 & 4 & 2620 & 12 \\
\hline $\begin{array}{l}\text { Promote } \\
\text { gambling }\end{array}$ & 455 & 9 & 122 & 3 & 1000 & 5 & 202 & 6 & 889 & 7 & 2668 & 11 \\
\hline $\begin{array}{l}\text { Promote } \\
\text { promiscuity }\end{array}$ & 542 & 9 & 345 & 10 & 1568 & 8 & 289 & 8 & 909 & 7 & 3653 & 6 \\
\hline $\begin{array}{l}\text { Promote late } \\
\text { night activities }\end{array}$ & 499 & 10 & 333 & 10 & 1829 & 10 & 359 & 10 & 1121 & 9 & 4141 & 3 \\
\hline $\begin{array}{l}\text { Inadequate } \\
\text { security }\end{array}$ & 542 & 10 & 219 & 6 & 1555 & 8 & 377 & 11 & 720 & 6 & 3413 & 8 \\
\hline Total & 5207 & 12 & 3495 & 8 & 19093 & 8 & 3494 & 8 & 12149 & 5 & 43438 & \\
\hline
\end{tabular}

Source: Researcher's field survey, 2018 


\section{Challenges hindering tourism development in the area}

The study examined the major challenges faced by tourism support outfits within the study area. Information on Fig. 6 revealed that challenges such as high cost of tax rate was the highest recorded challenge with $30 \%$ of respondents opinion, closely followed by lack of electricity supply with $20 \%$ response, lack of government supports with $12 \%$ and lack of security with $10 \%$. Meanwhile, the least challenge was lack of capital with $6 \%$ of the entire respondents.

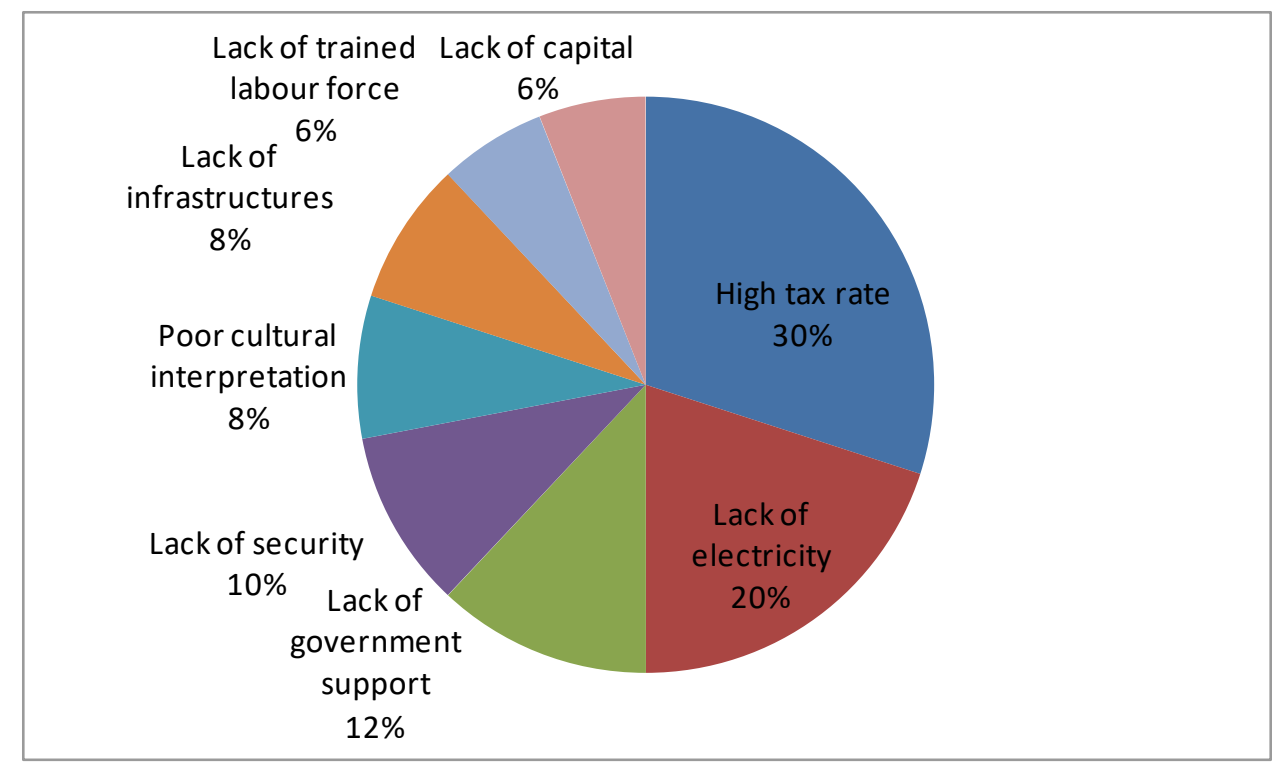

Figure 6. Challenges limiting the development of tourism in the area

\section{Discussion of Findings}

Recreational resorts has a lot of socio-economic implications to people as it contributes immensely in the economy of local people and host communities and also have implication on the environment as it improves infrastructural development but diminishes the quality of the environment if not properly managed or planned. The study also emphasized that awareness and knowledge of the local people on the importance of recreational activities is very vital to actualize the objective of establishing the recreational resorts in the area.

The study examined the medium of awareness of the visitors to the various recreational resorts. It was observed that the highest source of awareness came from family and friends with $36 \%$ attracted patronage while the least influential medium was from those who got their awareness from the electronic media with $12 \%$ of the overall patronage. In terms of employment, it was observed that the recreational resorts had significant impact on the economy of the residents in the area as five selected resorts had a total number of 179 employed workers with cleaners making up the majority of staffs with 44 workers while the least were chefs and laundry attendant with 7 workers each. In terms of remuneration, it was observed that a total of N2,408, 500 (two million four hundred and eight thousand and five hundred naira) was gotten annually by the workers in the five selected resorts.

The study analysis confirmed that the number of employed workers varied significantly across the various resorts with $(\mathrm{F}=5.243 ;<0.05)$ and the variation across the different classes of employment varying significantly with F-ratio of $(\mathrm{F}=8.383 ;<0.05)$. In terms of benefits accruing from the resorts to the residents, it was observed that the resorts provided opportunities for more businesses, employment and income to the people while the major challenges ranged from lack of publicity, maintenance and late night activities.

Finally, the study observed that lack of government support with $12 \%$ response level, lack of security with $10 \%$ response and lack of infrastructure with $8 \%$ response level were the highest perceived challenges hindering the growth of tourism in the area. 


\section{Conclusion and Recommendation}

The study examined the influence of recreational resorts in the socio-economic development of the Calabar, Cross River State. The findings of the study clearly indicate that information from family and friends is very vital in creating awareness of recreational activities in a destination area. Other notable sources of awareness are electronic media, print media and social media. The study revealed that the resorts played a pivotal role in the socio-economic development of the residents in the area as it provided the residents with opportunities to more businesses or investment, more jobs, generation of income and enhancement of their infrastructures. Irrespective of the benefits, the study also observed that challenges such as lack of government and private sector interest, poor roads, inadequate security and untrained personnel hindered the success of the tourism industry in the study area. Based on these findings, it was recommended that government of Cross River State should direct interest in investing in the tourism industry through collaboration with private investors and providing an enabling business environment by the reduction of tax, provision of loan facilities and provision of infrastructures in the study area.

\section{Conflict of Interest}

The authors declare that there is no conflict of interest.

\section{References}

[1] T.E. Amalu, A.O. Ajake, Developing natural lakes for socio-economic development: The case of Nike Lake, Enugu State Nigeria, GeoJournal. 78(4) (2018).

[2] T. Takon, T.E. Amalu, Assessment of natural resource conservation in Boki Local Government area, Cross River state, Nigeria, Environmental Science: An Indian Journal. 8(4) (2013) 123-131.

[3] E.I. Eja, A.O. Ajake, Seasonal changes on resort patronage in Cross River State, Nigeria, European Journal of Tourism, Hospitality and Recreation. 2(2) (2011) 19-30.

[4] T.E. Amalu et al., Socio-economic implication of tourists' appraisal of the Obudu Mountain resort, Cross River State, Nigeria, Journal of Environmental Science, Toxicology and Food Technology. 1(3) (2012) 37-44.

[5] T.E. Amalu, A.O. Ajake, The impact of hotel industry development in Enugu City, Nigeria, Journal of Tourism and Heritage Studies. 4(1\&2) (2015) 106-120.

[6] E.E. Iwara, T.E. Amalu, Assessing the seasonal patterns of visitors arrivals as an index for hotel industry growth in Calabar, Nigeria, Journal of Tourism and Management Research. 2(3) (2017) 135-146.

[7] T. Takon, T.E. Amalu, D. Okpara, Assessment of local people's attitude towards natural resource conservation in Boki Local government area, Cross River state, Nigeria, Research Journal in Organizational Psychology and Education Studies. 2(2) (2013) 60-66.

[8] T.E. Amalu, Community people's participation in tourism development in Obudu Mountain resort Cross river State, Nigeria, Lambert Publishers, Germany, 2012.

[9] M. Mowforth, I. Munt, Tourism and sustainability: New tourism in the Third World. London, Routledge, 2008.

[10] D.R. Hall, Ecotourism in the Danube Delta, The Tourist Review. 3 (2008) 11-13.

[11] R.J. Reeder, S.D. Calhoun, Federal funding in the Delta, Rural America. 17(4) (2002) 20-30.

[12] D.W. Marconiller, Outdoor recreation and rural development, in: E.M. Gary, R.F. Donald, (Eds.), National parks and rural development: practice and policy in the United States, Washington, DC: Island Press, 2000, pp. 33-49. 
[13] J. Zhang, R.J. Inbakaran, M.S. Jackson, Understanding community attitudes towards tourism and host-guest interaction in the urban-rural border region, Tourism Geographies. 8(2) (2006) 182-204.

[14] K.M. Johnson, C.L. Beale, Nonmetro recreational countries: Their identification and rapid growth, Rural America. 17(4) (2002) 12-19.

[15] F. Lawson, M. Baud-Bovy, Tourism and recreation development: A Handbook of physical planning, ACBI publishers Co. Inc., London, 2006.

[16] T.E. Amalu, A.O. Ajake, An assessment of the employment structure in the tourism industry of Obudu Mountain resort, Cross River state, Nigeria, Geo-Journal of Tourism and Geosites. 9(1) (2012) 35-56.

[17] M.J. Barnett, D.J. Smith, M. Haeffner, Influence of recreational activity on water quality perceptions and concerns in Utah: A replicated analysis, Journal of Outdoor Recreation and Tourism. 22 (2018) 26-36.

[18] A. Sava, Factors affecting the choice of recreational providers: A conceptual model, $2^{\text {nd }}$ Global Conference on Business. Economics, Management and Tourism, 30-31 October, Prague Czech Republic, 2015.

[19] A.O. Ajake, T.E. Amalu, The relevance of tourism on the economic development of Cross River state, Nigeria, Journal of Geography and Regional Planning. 5(1) (2012) 11-25.

[20] A.O. Ajake, T.E. Amalu, Participation of Becheeve people in tourism development in Obudu Mountain resort, Cross River state, Nigeria, British Journal of Humanities and Social Sciences. 3(2) (2012) 25-39.

[21] T.E. Amalu et al., Socio-Economic impacts of ecotourism attractions in Enugu state, Nigeria, GeoJournal. (2017) 1-13.

[22] T.E. Amalu et al., Assessment of tourists' patronage of Obudu mountain resort, Cross River state, Nigeria, Journal of Hospitality and Management Tourism. 8(4) (2017) 32-41.

[23] T.E. Amalu, A.O. Ajake, Influence of Calabar carnival on the economy of residents of Calabar metropolis, Cross River state, Nigeria, Global Journal. 1(1) (2014) 67-81.

[24] K. Roberts, Leisure in contemporary society, $2^{\text {nd }}$ ed., Shire Uk, Oxford, 2006.

[25] I.A. Enang, A.O. Ajake, T.E. Amalu, Volumetric analysis of tourist arrivals in ecotourism sites of Cross River state, Nigeria, Journal of Tourism and Management Research. 1(1) (2016) $135-154$.

[26] A.O. Ajake et al., Assessment of cultural and museum landscapes for tourism development: The Calabar museum scenario, Cross River State, Nigeria, Journal of Tourism and Management Research. 1(1) (2016) 119-134.

[27] E. De Kadt, Social Planning for tourism in the developing countries, Annals of Tourism Research. 6(1) (2006) 36-48.

[28] C.L. Jenkins, Tourism policies in developing countries, in: S. Medlik (Ed.), Managing Tourism. Oxford, Butterworth-Heinemann, 2010, pp. 269-278.

[29] T.E. Amalu et al., Assessment of the influence of Education on tourism development in Enugu state, Nigeria, American Journal of Tourism Research. 1(1) (2012) 33-42.

[30] T.E. Amalu, A.O. Ajake, P.O. Obi, Impact of royalties from forest resources on community development in Boki Local Government in Cross River state, Nigeria, GeoJournal. 80(1) (2015) 122-135. 
[31] S. Britton, The political economy of tourism in the Third World, Annals of Tourism Research. 9(3) (1982) 331-358.

[32] J. Bryden, Tourism and development: A case study of the Common Wealth Caribbean, Cambridge, Cambridge University Press, 2000.

[33] R. Butler, The concept of a tourist area cycle of evolution: Implication for management of resources, Canadian Geographer. 24(1) (1980) 5-12.

[34] J. Krippendorf, The holiday makers: Understanding the impact of leisure and travel, Oxford, Butterworth Heinemann, 2009. 